DOI: $10.15679 /$ bjwr.v4i2.55

\title{
IMPACT OF FREE-RANGING EUROPEAN BISON TO ECOSYSTEMS IN FRAGMENTED LANDSCAPE, LITHUANIA
}

\author{
Kibiša $A^{1}$.,Marozas $V .^{1}{ }^{1}$, Talijūnas $D .^{1}{ }^{1}$, Papšys $R^{2}{ }^{2}$, Sabalinkiene $G^{1}{ }^{1}$, Šimkevičius $K{ }^{1}{ }_{1}$
}

Summary: European bison (Bison bonasus L.) is the largest herbivore in Europe. Historically, it was distributed throughout western, central, and south-eastern Europe. Habitat degradation and fragmentation due to agricultural activity, forest loggings, and unlimited hunting were the main reasons for the decrease and extinction of European bison populations. In Lithuania, European bison were exterminated in the seventeenth century, but reintroduced in 1969. The species is still included in the country's Red Data Book. The first free ranging herd was established in 1973. Currently, the population of 186 free-ranging European bison individuals could be observed in the central part of the country - Panevezys and Kedainiai regions. European bison are spread in a highly anthropogenic agricultural landscape. Free-ranging European bison spend most of their time in forested areas, semi-open areas and forest fragments in agro-lands and agricultural fields, causing high damage rate to local farmers. They prefer young coniferous stands to mature and over-mature hardwood or softwood deciduous stands. In agricultural fields they prefer grain and corn to rape, leguminous or perennial grass. Recently, the amount of damage compensation reached 98820 euros per year. A test of a new method for evaluating the damage to agricultural fields caused by bison was successfully used by analysing orthophotoplan, obtained by using unmanned aircraft.

Key words: agroecosystems, bison, forest, vegetation

\section{Introduction}

European bison (Bison bonasus Linnaeus, 1758) is the largest herbivore in Europe. Historically, it was distributed throughout western, central and south-eastern Europe. The original bison population decreased drastically in western Europe. Overharvesting in combination with climate change and habitat loss are the likely causes of the extinctions (Meffe and Carroll, 1997; Wroe et al 2006; Mysterud et al 2007). Habitat degradation and fragmentation due to agricultural activity, forest loggings, and unlimited hunting and poaching, were the primary reasons for the decrease and extinction of European bison populations. By the end of $19^{\text {th }}$ century, there were only two populations of European bison left in the wild : in Białowieża Forest (B. b. bonasus) and in the West-Caucasus Mountains (B. b. caucasicus) (Pucek 2004). World War I completed the inevitable, making it impossible to avoid the final disaster in 1919. During the period of World War I and the Revolution of 1917, civil war episodes and heavy poaching became directly responsible for the complete extirpation of European bison in the west-Caucasus region before 1927 (Bashkirov 1940; Heptner et al. 1966; Pucek 2004). Last alive female was shot in Bialowieza forest in 1919. After World War I, the species survived only in a few European zoological gardens (Sztolcman 1924). Together there were only 54 (29 males; 25 females) European bison with proved pedigrees (Raczyński 1978), originating from 12 ancestors (or founder animals) (Slatis 1960). Lithuania was

\footnotetext{
${ }^{1}$ Artūras Kibiša. PhD student; Vitas Marozas, profesor; Dovydas Talijūnas, master student; Gintare Sabalinkienė, PhD, lecturer; Kastytis Šimkevičius, lecturer; Aleksandras Stulginskis University, Faculty of Forest Sciences and Ecology, Institute of Forest Biology and Silviculture. Studentu Street 9, Akademija, Kaunas district, LT-53361 Lithuania,

${ }^{2}$ Rytas Papšys, qualified bison expert, Ministry of the Environment, Kaunas district, LT-53361 Lithuania,

Corresponding author: Gintare Sabalinkiene, gintare.sabalinkiene@asu.lt
} 
one of the countries where European bison was reintroduced. Enclosure for bison was built in the central part of the country and first bison were released there from Russia in 1969. Bison were breeding successfully and first young individuals born in enclosure were released to wild forest near the enclosure in 1971. Slowly, a free ranging bison herd was formed. However, breeding rates of wild population were not very high in the beginning. Population of $20-30$ individuals were living sedentary in Panevezis region, divided to separate herds of males and females with juveniles. This population size did not cause serious problems to forestry and agriculture. Since 2003 the population size has been increasing and the current population size is nearly 200 individuals. Such population size is not high, but having in mind that these animals live sedentary in Panevezys and Kedainiai regions, where soil productivity is the highest in the whole country, bison cause large and concentrated damage to silviculture and agriculture. The development of agricultural crops more than 10,000 years ago has resulted in substantial changes in human society and in landscape structure. With the domestication of plant species, humans established permanent settlements, instead of hunter-gatherer lifestyles that they had led before. However, domestication of plant species also brought increased investments in time, infrastructure and natural resources (e.g. fertilisers and water) in order to increase production and secure food supplies. This concentration of food for humans also created high quality food resources for wildlife that led to increased interaction between people and wildlife (Gordon 2009). European bison, the largest mammal in Europe, after being exterminated in the wild and then restored during the $20^{\text {th }}$ century, is still listed by the International Union for Conservation of Nature (IUCN Red List of Threatened Species) as a species vulnerable to extinction. However, the increasing number of European bison, through creation of new and expansion of the existing populations, has strongly increased the risk of humanbison conflict in the near future (Hofman-Kaminska and Kowalczyk 2012).

Subsequent reintroductions of European bison into the wild started in Bialowieza Forest in 1952 (Krasinski 1978). The reintroduction of this nearly extinct species - European bison was successful in Lithuania as well as in some other European countries. European bison (Bison bonasus L.) is the unique species among the group of European Pliocene wild bovines as it has survived until now (Katalog 1981). However, nowadays in Europe they are scattered in small populations and face problems of inbreeding, mainly due to the historical bottleneck of population numbers in the early $20^{\text {th }}$ century (Pucek, 2004) and fragmentation of contemporary populations (Perzanowski et al., 2004). In Europe, bison population consists of small and isolated herds whose survival depends on creating larger and connected populations. Detailed knowledge of movement and habitat use in human-dominated landscape is essential for further successful reintroductions of the European bison (Červeny et al 2014).

The main objective of the present conservation strategy is to create conditions suitable for the long-term survival of wild bison populations by increasing the genetic diversity of the existing populations and extending their distribution range (Pucek et al . 2004; Krasińska and Krasiński 2007). The conservation success will depend on increasing the population size and linking local, isolated populations into a large meta -population through natural or assisted transfers of animals (Pucek et al. 2004; Krasińska \& Krasiński 2007; Ziółkowska et al. 2012). This requires increasing the connectivity of subpopulations (Červeny et al 2014).

The aim of the present study was to evaluate bison preferred habitats in the vegetative season and to determine bison the influence on the ecosystems in the fragmented landscape in their home range area. 


\section{Material and Methods}

As the size of free-living European bison population has increased considerably in Lithuania, the requirements of damage compensation have increased as well (Figure 1). The population size of free living bison is only about 200 individuals.

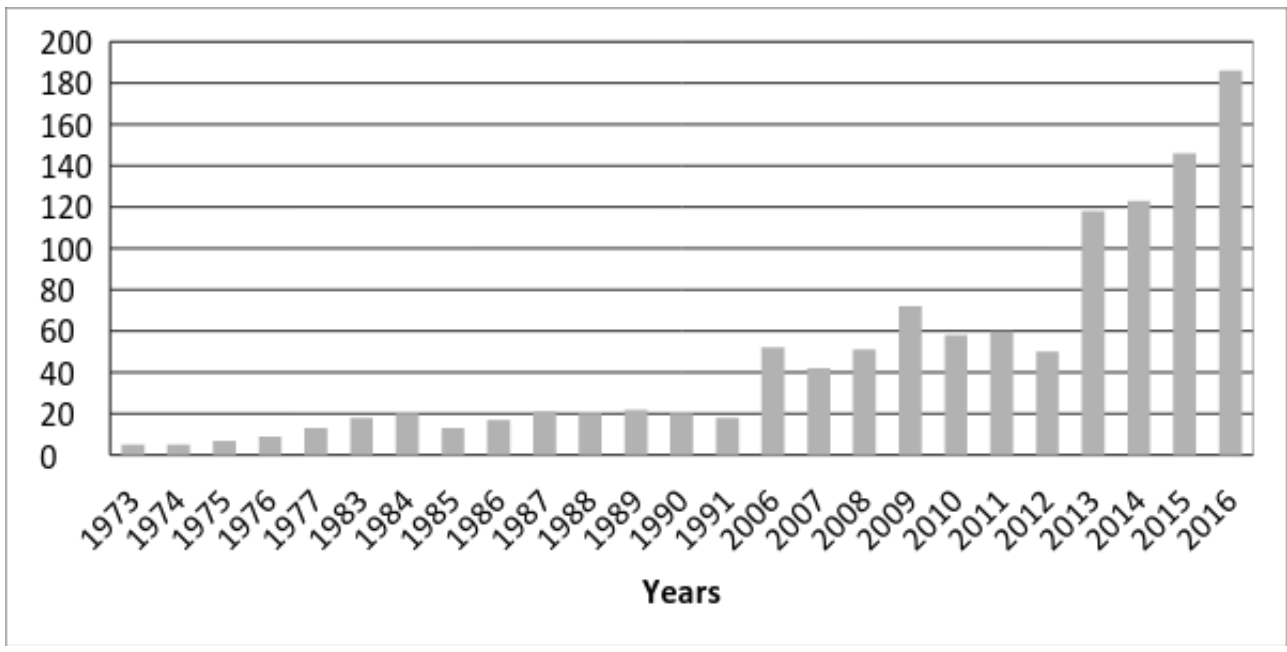

Figure 1. The dynamics of bison population size in Lithuania (Data source: Ministry of Environment)

But the fact that they live sedentary in the area of 57183 ha in the central part of the country, with the most efficient soil productivity, cause a concentrated and high damage to local farmers and forest owners. Recently, the amount of damage compensation has reached 98820 euros per year (Figure 2). In order to reduce the damage, the Ministry of Environment have decided to spread the concentrated bison population, by transferring young individuals from freedom to two new enclosures in Telsiai and Druskininkai regions.

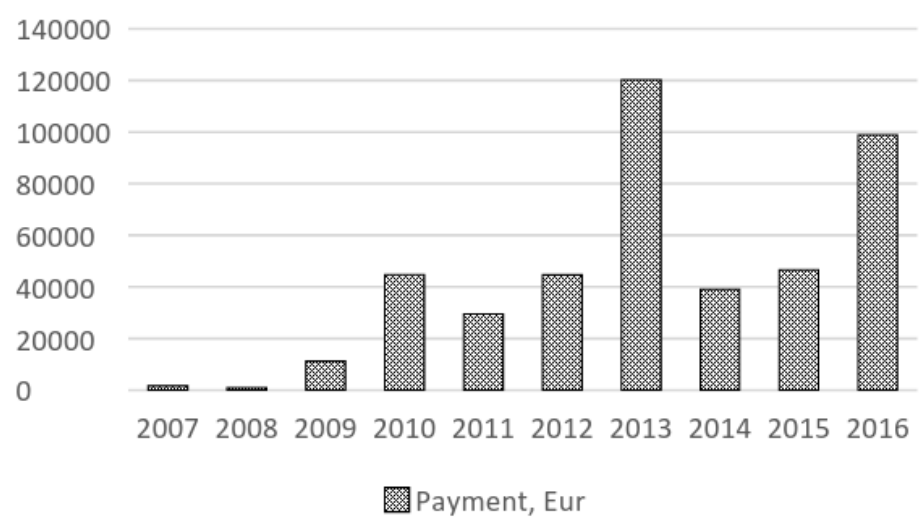

Figure 2. Payment amount (Euro) for damage compensation caused by free range European bison in Lithuania 
So far, every bison has been captured in the wild and released in enclosures. But in order to track them, one female bison was captured and fitted with a GPS collar by specialists from the Ministry of Environment. This collared female is living in a herd of females with juveniles, consisting of 33 individuals. Thus, tracing one collared female we get information of movements of 34 individuals. GPS collar is sending information with coordinates every 8 hours. We have analysed the data collected in the vegetation season of 2016, between March and September.

We have analysed the home range size of the traced herd by months (by Minimum Convex Polygon $100 \%$ method), the bison distribution by different habitats, forest stand age, tree species composition and agricultural crops. To study habitat preferences, we used Jacobs' index (Jacobs 1974): $\mathrm{D}=(\mathrm{r}-\mathrm{p}) /(\mathrm{r}+\mathrm{p}-2 \mathrm{rp})$, where $\mathrm{r}$ is a fraction of a habitat among habitats used by bison and $\mathrm{p}$ is a fraction of a habitat in the forest. $\mathrm{D}$ values range -1 for maximum avoidance to +1 for maximum positive selection.

In the home range area of the traced bison herd we have performed damage evaluation to agriculture caused by the bison herd. To evaluate the damage to agriculture caused by 34 bison herd we have chosen one field of winter wheat, visited by the bison most often during our observation period. We have used and compared two different methods of damage evaluation: a) damaged area cover (\%) was identified using the methodology, approved by the Ministry of Environment (2002); b) damaged area cover (\%) was identified by ArcGIS programme, using aerophotograpgy, made by unmanned aircraft (drone).

\section{Results and Discussion}

The herd of the tracked bison occupies the area of 1207 ha of forest and intensively used agricultural field, which is partly isolated by highway E67 from one side, railway from other side and water dump and urban areas from the third side. The tracked herd of bison entered this area, which they hadn't inhabited before, while one female was captured and fitted with a collar on $2^{\text {nd }}$ March. It is possible that the herd of 34 individuals does not cross the "borders" of this semiisolated area due to high disturbance rate. They do not cross intensively used highway or railway, they do not get too close to villages and do not cross large water bodies.

Moreover, home range size of the bison is decreasing every month (Figure 3), most likely due to high food resources in the vegetation period.

The home range size by separate months decreased as follows: March - 763 ha; April - 745 ha; May - 608 ha; June - 476 ha; July - 400 ha; August - 320 ha and from September it started to increase again and reached 394 ha. Cerneny et al (2014) found that the traced bison herd used the smallest area in June, while the largest area is used in April. Their results show that the average size of home range during the growing season (April - September) is the territory of 29.5 ha. At the end of summer, the herd of bison tends to concentrate more in forested areas. This could be due to increased disturbance by works in agricultural fields - fertilization, spray of pesticides, mowing and threshing. It is possible that decreased supply of food recourses in late autumn, and winter will force bison herd to increase their home range again.

Although the total semi-isolated area occupied by the bison herd is dominated by open agricultural areas,, they spend most of the time in the forest (0.43) (Černeny et al 2014). 


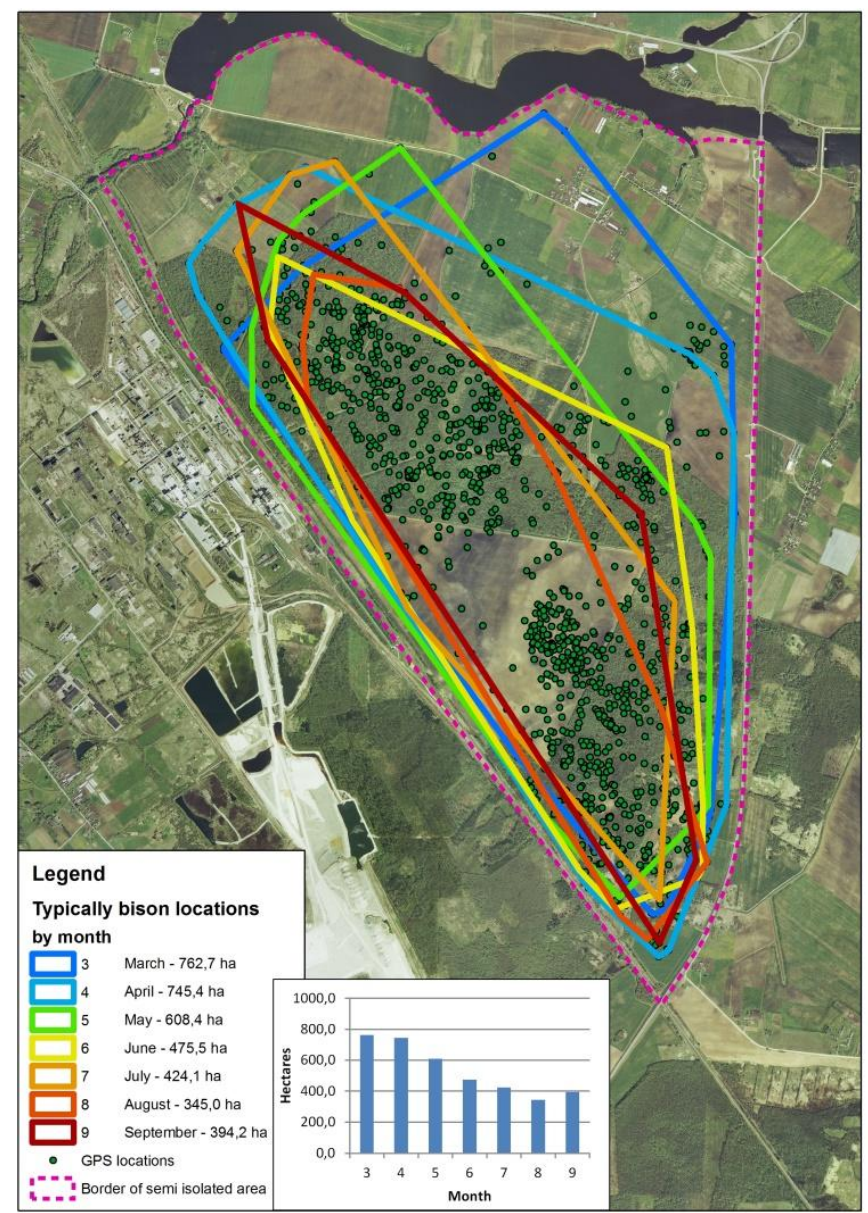

Figure 3. The variation of bison herd home range size among months (from March to September)

Our results showed that bison prefer naturally dry and temporary wet habitats, avoiding wet areas, wetlands, swamp and marsh. This area is dominated by middle-mature, mature and over-mature forests (Figure 4), which is contrary to the results of Černeny et al (2014), which stated that bison preferred young stands to clear cutting areas or over-mature stands (Figure 5).

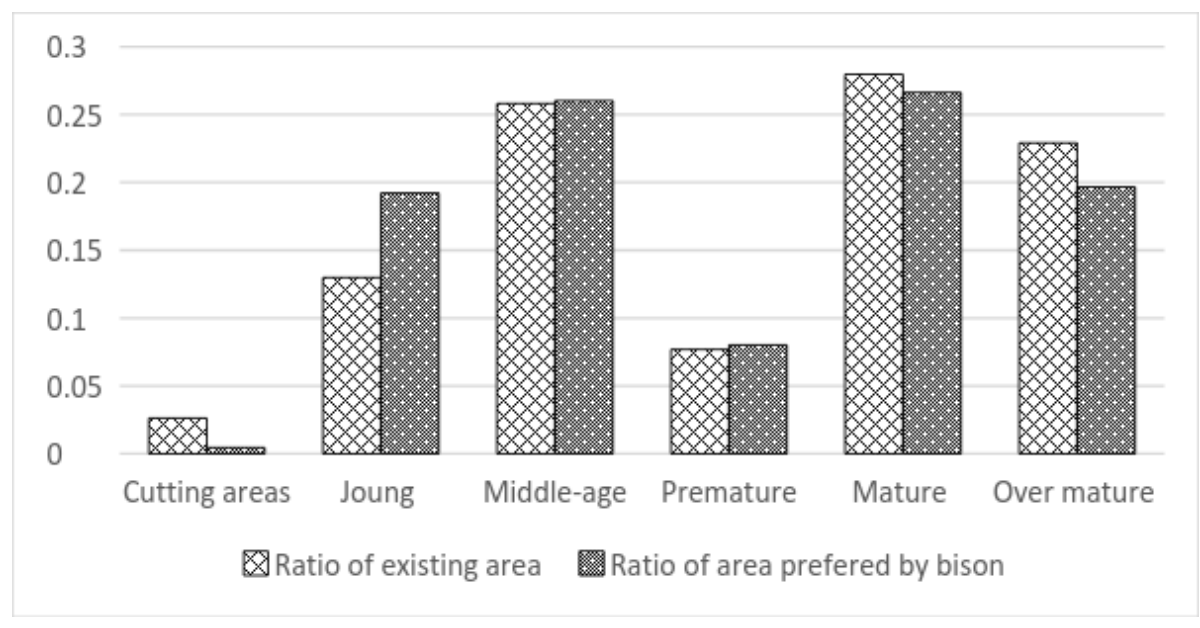

Figure 4. Forest maturity groups, present and preferred by bison 


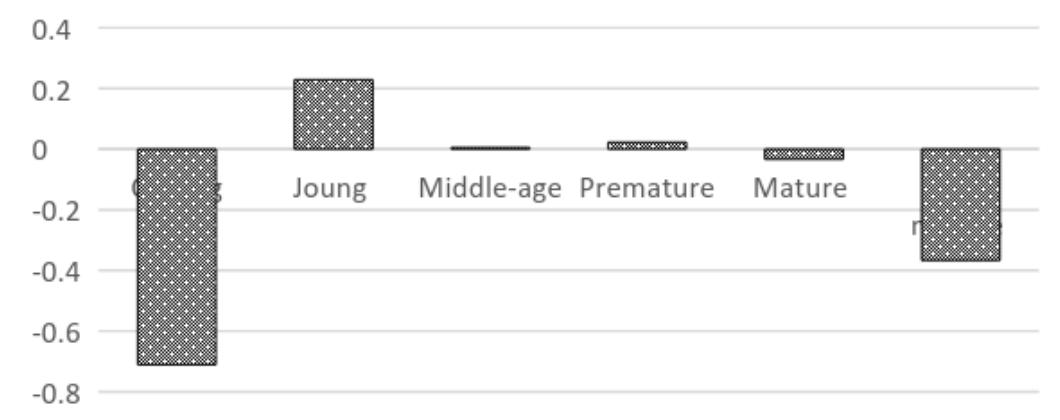

Figure 5. Jacobs index shows bison preference of stand maturity groups

Concerning tree species composition, bison were observed most of the time in forest stands dominated by coniferous trees (Figure 6) (Černeny et al 2014). Although previous studies showed that bison prefer deciduous forests (e.g. Krasińska and Krasiński 2007; Kuemmerle et al. 2011), Brandtberg and Dabelsteen (2013) reported that the reintroduced bison at a Danish island preferred coniferous forest stands during the growing season. We found that bison prefer hard deciduous species stands to soft deciduous species stands. They generally preferred spruce, pine, ash and birch dominated stands, while they avoided elm, lime and willow. We shall also mention that bison preferred cultural forest stands (0.069), more than self-regenerated stands (0.037) Also, they avoided open areas, clear cuts and open swamps $(-1)$.

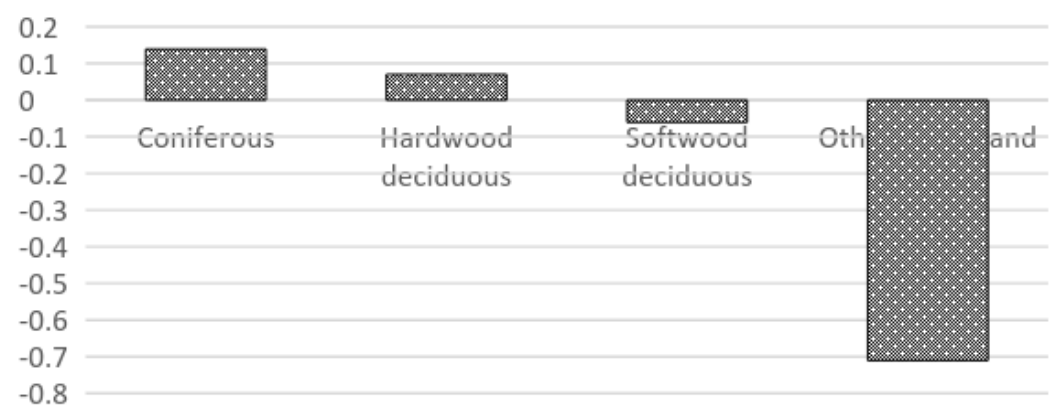

Figure 6. Jacobs index shows dominated tree species composition, preferred by bison herd

Concerning agricultural fields, grain and corn crops were most present in the home range of the tracked bison herd, while leguminous, rape and perennial grasses were found on small areas. Our results show that the bison preferred grain $(0,1)$ crops and corns $(0,08)$, while they totally avoided leguminous (-1), rape (-1) and perennial grasses (-1) (Figure 7).

Large animals may cause huge economic losses in agriculture and forestry (Apollonio et al 2010). The increasing number of ungulates in Europe indicates that there will be an increase in human wildlife conflict and the costs of crop depredation (Hofman - Kaminska and Kowalczyk 2012). As European bison population size in Lithuania is increasing, the damage compensation to farmers is increasing, as well (Figure 5). This forces the government to make decisions for proper bison population management. To maintain the idea of promoting good quality bison population over Europe, bison population should not be decreased by hunting. The decision was to split and move a part of the existing population members to new areas - two new enclosures in diverse regions of 
Lithuania. However, every free living bison was captured and placed into new areas. Thus, the damage problem is still relevant. For damage rate estimation we have used ortophotoplan, received by unmanned aircraft equipped with photo cameras (drone).

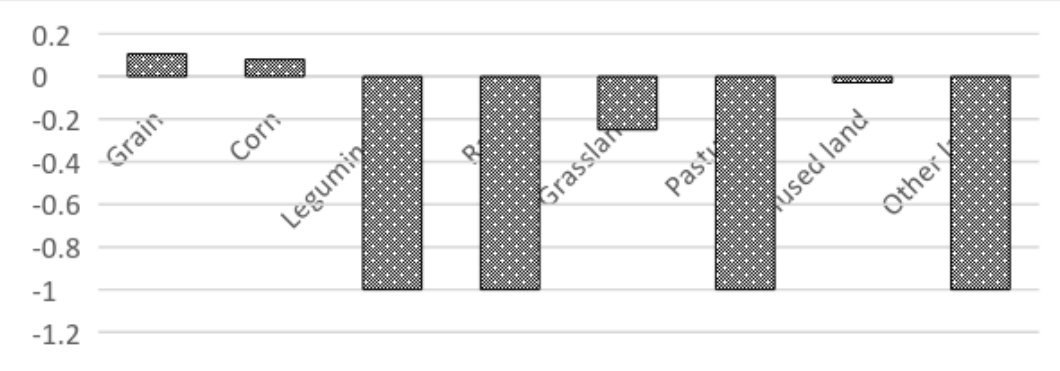

Figure 7. Jacobs index shows bison preference on agricultural fields

This was a new technique, never used in Lithuania before for estimation of damage caused by wildlife. However, in order to obtain sufficient quality photography, clear weather in needed. The orthophotoplan was analysed using ArcMap 10.2.2. programme. The challenge was to distinguish damage made by bison, wild boar and storm (rain + wind) in a photograph. To be sure, we have visited the field after taking a photograph and identified unclear places, by identification of the damage type, footprints in soil and excrement. We have estimated that the herd of bison damaged $70 \%$ of the yield. While using ordinary methodology approved by the Ministry of Environment, the estimated damage was only $50 \%$. The main reason of this difference is that we were able to see and evaluate the whole field from above. Using ordinary methodology, when estimating damage while standing on ground, does not allow observing all damaged areas. We can conclude that damage evaluation method using photography from aircraft was more efficient.

\section{Conclusion}

Abundant food supply and increased disturbance in open agriculture areas led the bison herd to minimize their home range size twice from March to August. Most likely, home range size will increase in late autumn or winter, when available food recourses will be reduced. The bison preferred young forest stand with coniferous dominated dense forest stands, while they avoided open forest areas, clear cuts, as well as over-mature forest stands dominated by soft deciduous tree species. In agricultural areas the bison preferred grain and corn field, while they completely avoided rape, leguminous and perennial grasses.

The new method of estimating damage to agricultural yield caused by bison give more proper results than the ordinary method. However, this method requires clear weather while taking pictures from aircraft in order to distinguish the damage causing agent. Most often, wild boar (Sus scrofa) feeds on the same area as bison.

\section{References}

1. Bashkirov I. 1940. Kavkazskii zubr. Monograficheskii ocherk Pp. 7 - 72 in: Kavkazskii zubr. (ed. N.K. Kulagin). Glavnoe Upravlenie po zapovednikam, zooparkam I zoosadam. Moscow, USSR.

2. Brandtberg N.H., Dabelsteen T. 2013. Habitat selection of two European bison (Bison bonasus) on the Danish island Bornholm. Europen Bison Concervation Newsletter, 6:73 - 80. 
3. Červeny J., Ježek M., Hola M., Zikmund M., Kušta T., Hanzal V., Kropil R. 2014. Daily activity rhythm and habitat use of the semi-free European bison herd during the growing season. Lesnicky časopis - Forestry Journal 60: 199 - 204.

4. Gordon J.I. 2009. What is the fiture of wild, large herbivores in human-modified agricultural landscapes? Wildlife Biology 15: $1-9$.

5. Heptner V.G., Nasimovic A.A., Bannikov A.G. 1966. Die Saugetiere der Sovietunion. 1. Paarhufer und Unpaarhufer. G. Fischer Verl. Jena, Germnay. Pp. 1-939.

6. Hofman-Kaminska E., Kowalczyl R. 2012. Farm Crops Depredation by European Bison (Bison bonasus) in the Vicinity of Forest Habitats in Northeastern Poland. Environmental Management 50: 530 - 541.

7. Jacobs, J. 1974. Quantitative measurement of food selection. Oecologia (Berl.), 14: 413-417.

8. Katalog mlekopitajuwih SSSR (pliocen-sovremennost). 1981. (I.M. Goromova and G.I. Baranovoj eds.). Nauka, Lviv: 380-383 pp.

9. Krasinska M., Krasinski Z.A. 2007. European bison, a nature monograph. Mammal Research institute, Polish Academy of Science, Bialowieza, 221 p.

10. Krasinski Z.A. 1978. Dynamikcs and structure of the European bison in the Bialowieza Primeval Forest. Acta Theriologica, 23: $13-48$.

11. Kuemmerle T., Radeloff V.C., Perzanowski K., Kozlo P., Sipko T., Khoyetskyy P., Bashta A.T., Chikurova E., Parnikoxa I., Baskin L., Angelstam P., Waller D. 2011. Predicting potential European bison habitat across its former range. Ecological Applications, 21:830 - 843.

12. Meffe G.K., Carroll C.R. 1997. Principles of conservation biology. Sunderland, M.A: Sinauer.

13. Mysterud., Barton K.A., Jędrzejewska B., Krasinski Z.A., Niedzialkowska M., Kamler J.F., Yoccoz N.G., Stenseth N.C. 2007. Population ecology and concervation of endangered megafauna:the case of European bison in Bialowieza Primeval Forest, Poland. Animal Concervation 10: 77 - 87.

14. Perzanowski K., Olech W., Kozak H. 2004. Constraints for re-establishing a meta-population of the European bison in Ukraine. Biological Concervation, 120: 345-353.

15. Pucek Z. Status Survey and Conservation Action Plan European Bison. The World Conservation Union, 2004

16. Raczynski J., 1978. Žubr [European Bison]. Panstwowe Wydawnictwo Rolnicze I Lesne, Warsaw, Poland. Pp. 1 - 246.

17. Slatis H.M. 1960. An Analysis of inbreeding in the European bison. Genetics 45: 275 - 287.

18. Sztolcman J. 1924. Materiaux pour l'histoire naturelle et pour l'historique du Bison d'Europe (Bison bonasus Linn.). Annales Zoologici Polonici Historiae Naturalis, 2: 49 - 136.

19. Wroe S., Field J., Grayson D.K. 2006. Megafaunal extinction: climate, humans and assumptions. Trends in Ecology and Evolution. 21, $61-62$.

20. Ziolkowska E., Ostapowicz K., Kuemmerle T., Perzanowski K., Radeloff V.C., Kozak J. 2012. Potential habitat connectivity of European bison (Bison bonasus) in the Carpathians. Biological Concervation, 146: 188 - 196.

Received: 14.05.2017.

Accepted: 23.12.2017.

Kibisa A., Marozas V., Talijunas D., Papsys R., Sabalinkiene G., Simkevičius K. (2017). Impact of free-ranging European bison to ecosystems in fragmented landscape, Lithuania, Balkan Journal of Wildlife Research, 4(2), pp. 18-25. 